\title{
Visible-Light Active Nanomaterials for Environmental Remediation - A Mini Review
}

\author{
Nirupama ${ }^{1}$, Badal Kumar Mandal 1,*(i) \\ 1 Trace Elements Speciation Research Laboratory, Department of Chemistry, School of Advanced Sciences, Vellore \\ Institute of Technology (VIT), Vellore- 632014, India \\ * Correspondence: badalmandal@ vit.ac.in (B.K.M.);
}

Scopus Author ID 7102080708

Received: 1.04.2021; Revised: 5.05.2021; Accepted: 9.05.2021; Published: 18.06.2021

\begin{abstract}
For the past few decades, industries like dyeing, paper, and textile industries have been releasing potentially hazardous substances which may affect human health. The majority of the pollutants present in water bodies comprise dyes. Although various traditional methods have been employed to treat wastewater from industries, recent advances in technology depict tapping of solar energy using visible light photocatalysts to remove toxic dyes hazardous to health. Nanomaterials have proved to enhance the properties of any material they are incorporated into, especially due to their increased surface areas in the case of catalysts, resulting in more interaction with the substrate. The uses of nanomaterials in photocatalytic degradation activities have also proven to increase degradation efficiencies. The present study is intended to provide a broad overview of the various contaminants, especially dyes, polluting the environment and the visible-light-active nanomaterials-related technologies available for their degradation. Further, the advantages of using such materials and technologies in improving the environment and human health will be discussed in detail, and the foundation for further development in this area will be highlighted.
\end{abstract}

Keywords: visible light active nanomaterials; environmental remediation; photocatalyst; photodegradation.

(C) 2021 by the authors. This article is an open-access article distributed under the terms and conditions of the Creative Commons Attribution (CC BY) license (https://creativecommons.org/licenses/by/4.0/).

\section{Introduction}

Many industries have been releasing potentially hazardous pollutants to the environment for the past few decades, affecting human health [1]. Large volumes and the complex nature of effluents released from textile industries pose a major threat to the environment. It has been observed that dyes form the major component of the pollutants present in water bodies. Dye colors affect the quality of water and hence disrupt the aquatic ecosystem. Due to the carcinogenic, genotoxic, and mutagenic nature of dyes and their partial breakdown resulting products, it causes serious health effects to humans [2]. The conventional methods used to treat water are adsorption, oxidation processes, flocculation, ultrafiltration, etc. But most of these methods do not completely convert the dyes into non-toxic inorganic products like $\mathrm{CO}_{2}$ and $\mathrm{H}_{2} \mathrm{O}$, do not have high degradation efficiency, and recyclable and stable photocatalysts.

Several nanomaterials have been used to remove pollutants from the water body and surrounding environment. Especially, silver nanoparticles (Ag NPs) are used extensively as antimicrobial agents [2-6], while other nanomaterials such as silica NPs [7], gold NPs [8], Nano-Sized Zirconium Vanadate [9], titanium dioxide NPs [10], silver vanadate nanorods [11], copper oxide NPs [12], metal sequestration [13], copper NPs [14], zinc oxide NPs [15], nickel 
oxide NPs [16], and iron oxide NPs [17] are used pollutant remediation as well as water purification.

However, photocatalysis using solar energy can be used as a clean and cost-effective detoxification technology, using renewable and abundant energy to oxidize organic and inorganic compounds present in contaminated water to a non-toxic form [18-20]. Recently, semiconductor photocatalysts have been widely used for pollutant degradation. Free oxidizing species like hydroxyl and peroxide radicals, electrons, and holes are generated upon irradiation by light in the UV-visible region. Such materials should have the ability to efficiently separate generated electron-hole pairs and reduce their recombination rate for effective dye degradation [21]. The use of nanomaterials has widely increased in recent studies as they have proved to improve the properties of materials when incorporated in them with a higher turnover and efficiency rate. Moreover, nanomaterials play an important role in environmental remediation. It has been used to remove contaminants of size less than $300 \mathrm{~nm}$ from water bodies and less than $20 \mathrm{~nm}$ from the air [22].

The present study highlights the various visible-light active photocatalysts used for the degradation of dye pollutants. It discusses comparative degradation efficiencies and reaction rates of various photocatalysts.

\section{Available nanomaterials for photocatalytic degradation}

In this review article, few relevant papers published in ACS since 2012 are reviewed to study various nanomaterials used for photocatalytic degradation of toxic dyes. Black carbon (BC) soot is a globally generated pollutant with various negative effects on humans and the environment. Due to its high adsorption efficiency nanocarbons are derived from it and used for water filtration to remove organic dyes from contaminated water in a single step. Since graphene is one of the most important allotropes of carbon with high surface activities, graphene nanosheets (GNS) were isolated from the soot of waste petrol. Water-soluble graphene nanosheets (wsGNS) were synthesized by simple oxidation of soot using nitric acid and carboxylic acid groups were incorporated onto the surface, which is responsible for creating more active sites on the surface. High-density surface defects due to negative functional groups were confirmed by TEM, HRTEM, and XPS analyses. The wsGNS exhibit photoluminescent properties due to proton transfer between the carboxylate anion/hydroxyl and hydroxyl/hydroxyl moieties, which can be easily tuned by changing the degree of surface functionalization. The high-density surface defects increase the spatial separation between HOMO and LUMO, trap photoexcited electrons during visible light irradiation and generate oxygen radicals on the surface which are responsible for an efficient methylene blue (MB) dye degradation. Hydroxyl radicals also contribute to the degradation process. $96 \%$ of MB was degraded in 90 min by wsGNS, and its rate constant was $0.0313 \mathrm{~min}^{-1}$ compared to GNS, which degraded only $19.6 \%$ of MB with a rate constant of $0.0028 \mathrm{~min}^{-1}$ ( 11 times lower). Postdegradation studies of MB confirmed the destruction of the aromatic structure of the dye that resulted in smaller hydrocarbons as the degraded products. The degradation efficiency reduced to $90 \%$ after 3 cycles and $75 \%$ after 5 cycles of photocatalyst recycling. The synthesis of a highly stable, recoverable, and reusable photocatalyst derived from pollutant soot using a lowcost, facile, metallic contamination-free method is the advantage of this process [20].

A conducting polymer polyaniline/reduced graphene oxide (PANI/RGO) photocatalyst with sheet-like composites showed excellent degradation activity to rhodamine $\mathrm{B}(\mathrm{RhB})$ and malachite green (MG) cationic dyes and congo red (CR) anionic dye when compared to 
individual PANI or RGO photocatalysts. RGO helps prevent agglomeration of PANI nanoparticles which enhances the surface area, acts as an electron acceptor, and helps in increasing charge separation, thereby improving light absorption capability. The composite can absorb in the wavelength range of the entire solar spectrum, separating excited charge carriers rapidly, preventing electron-hole recombination, and reducing toxic $\mathrm{Cr}(\mathrm{VI})$. The decrease in the bandgap, firm attachment of RGO to PANI, and other structural details were confirmed by various spectral analyses like TEM, FESEM, XRD, and UV-vis spectra. BET analysis indicates a mesoporous structure of the sample with a surface area of $35.06 \mathrm{~m}^{2} / \mathrm{g}$. The PANI/RGO composite with $5 \mathrm{wt} \%$ RGO showed the highest degradation efficiency (99.68\%) for MG dye within 15 min followed by $99.35 \% \mathrm{RhB}$ and $98.73 \% \mathrm{CR}$ dyes within 30 and 40 min, when compared to individual PANI (61.07, 70.46, and 73.66\%) and RGO (91.54, 89.45, and 86.07\%) degraded MG, RhB, and CR dyes, respectively [23]. The rate constants of the PANI/RGO composite for $\mathrm{MG}, \mathrm{RhB}$, and CR degradations are $3.84 \times 10^{-1}, 0.168$, and $0.109 \mathrm{~min}^{-1}$, respectively. The photocatalytic activity was mainly found to be due to hydroxyl radicals and partly due to superoxide radicals and holes $\left(\mathrm{h}^{+}\right)$. The composite showed high photostability even after 6 cycles with degradation efficiencies of $99.68-86.63 \%$ for MG, $99.35-87.12 \%$ for $\mathrm{RhB}$ and $98.73-92.78 \%$ for CR. It also efficiently removed $94.7 \% \mathrm{Cr}(\mathrm{VI})$ at $\mathrm{pH} 2$ in just 15 minutes [23].

A highly permeable mesoporous $\mathrm{Cu}_{1.94} \mathrm{~S}-\mathrm{rGO}$ composite was synthesized by hydrothermal method as a photocatalyst for dye degradation and a modified $\mathrm{Cu}_{1.94} \mathrm{~S}-\mathrm{rGO} / \mathrm{GCE}$ phenol sensor which showed a good response toward phenol in $0.2 \mu \mathrm{M}$ to $1.4 \mu \mathrm{M}$ concentration range. Due to the smaller bandgap of the composite and lesser concentration of photogenerated radicals, the wet hydrogen peroxide catalytic oxidation method (WHPCO) is employed, resulting in high efficiency and low discharge of secondary pollutants in air and water. Attaching RGO to copper monosulphide enhanced electronic mobility. The photocatalyst's mesoporous nature with higher surface area leads to better adsorption of dye molecules and light energy. The successful synthesis of $\mathrm{Cu}_{1.94} \mathrm{~S}-\mathrm{rGO}$ and $\mathrm{GO}$ sheets was confirmed by SEM and TEM analyses. It also confirms the self-aggregation of $\mathrm{Cu}_{1.94} \mathrm{~S}$ to form corresponding nanoclusters, which are not evenly distributed on the GO sheet surface, proof for electrostatic interaction due to carboxyl groups on the surface of GO sheets. The average atomic ratio (\%) of $\mathrm{Cu}$ and $\mathrm{S}$ was found to be 1.932:1. XRD confirms the reduction of GO into RGO and the djurleite structure of synthesized nanoparticles, whereas EPR analysis confirms the +1 oxidation state of $\mathrm{Cu}$ in $\mathrm{Cu}_{2-\mathrm{x}} \mathrm{S}$ and $\mathrm{Cu}_{2-\mathrm{x}} \mathrm{S}-\mathrm{rGO}$. The BET analysis revealed a surface area of $16.12 \mathrm{~m}^{2} / \mathrm{g}$ for $\mathrm{Cu}_{1.94} \mathrm{~S}$ and $109.95 \mathrm{~m}^{2} / \mathrm{g}$ for $\mathrm{Cu}_{1.94} \mathrm{~S}-\mathrm{rGO}$. The average pore radius was 2.98 $\mathrm{nm}$ for $\mathrm{Cu}_{1.94} \mathrm{~S}-\mathrm{rGO}$ and $39.25 \mathrm{~nm}$ for $\mathrm{Cu}_{1.94} \mathrm{~S}$ calculated using the Barret-Joyner-Halenda (BJH) method. It was observed that the carbon framework disintegrates due to the removal of groups containing oxygen when the temperature rises from $250-800^{\circ} \mathrm{C}$. The composite shows enhanced absorption in the near-infrared region (NIR). The photodegradation rate of methyl

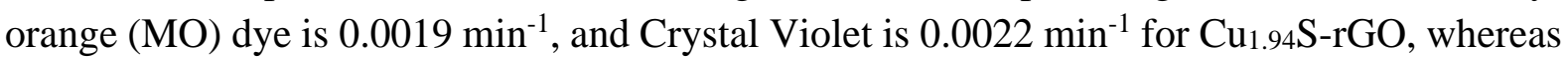
for $\mathrm{Cu}_{1.94 \mathrm{~S}}$, the rates are $0.0007 \mathrm{~min}^{-1}$ and $0.0010 \mathrm{~min}^{-1}$, respectively. The degradation rate also increases with an increase in the concentration of hydrogen peroxide. Moreover, dye removal efficiency is higher in the case of anionic crystal violet dye than MO as the photocatalyst has negatively charged hydroxyl groups on its surface. The $\pi-\pi$ interaction between crystal violet and the localized $\pi$ orbitals of conjugated aromatic rings of $\mathrm{r}-\mathrm{GO}$ sheets increases its adsorption to the surface of the photocatalyst. Hence, the degradation efficiency for Crystal violet is $90.76 \%$ with $0.55 \mathrm{mM} \mathrm{HP}$ dose and $79.44 \% \mathrm{RE}$ with $0.55 \mathrm{mM}$ HP dose for MO dye. Recycling 
the photocatalyst 4 times led to removal efficiency loss of only $\sim 6.8 \%$ for Crystal violet and $\sim 5.1 \%$ for $\mathrm{MO}[24]$.

$\mathrm{Ag} @ \mathrm{SnO}_{2}-\mathrm{g}-\mathrm{C}_{3} \mathrm{~N}_{4}$ nanostructures with spherical $\mathrm{Ag}$ nanoparticles were biogenically synthesized using a microorganism containing electroactive biofilm as a green, reducing tool for photocatalytic degradation of dye molecules such as $\mathrm{MB}, \mathrm{CR}$ and $\mathrm{RhB}$. The degradation efficiency of $6 \mathrm{mM} \mathrm{Ag@} \mathrm{SnO}_{2}-\mathrm{g}-\mathrm{C}_{3} \mathrm{~N}_{4}$ with a high number of $\mathrm{Ag}$ nanoparticles was $~ 99.4 \%$ for $\mathrm{MB}, \sim 98.28 \%$ for $\mathrm{CR}$, and $\sim 94.67 \%$ for $\mathrm{RhB}$, and the degradation completed in 90,60 , and 240 minutes, respectively. The degradation rate was highest for $6 \mathrm{mM} \mathrm{Ag@} \mathrm{SnO}_{2}-\mathrm{g}_{-} \mathrm{C}_{3} \mathrm{~N}_{4}$ compared to $1 \mathrm{mM}$ and $3 \mathrm{mM} \mathrm{Ag} @ \mathrm{SnO}_{2}-\mathrm{g}-\mathrm{C}_{3} \mathrm{~N}_{4}$ nanoparticles. Attaching Ag nanoparticles to $\mathrm{SnO}_{2}-\mathrm{g}-\mathrm{C}_{3} \mathrm{~N}_{4}$ lowered the electron-hole pair recombination rate and increased visible light photocatalytic degradation due to surface plasmon resonance. The photocatalyst is responsible for high electron mobility. Stability studies proved that there was no leaching of individual metals due to sonication. Hence the photocatalyst is highly stable. XRD analysis proved the purity and tetragonal rutile structure of $\mathrm{SnO}_{2}$. It also showed that the introduction of $\mathrm{Ag}$ improved the crystallinity of the material.

FT-IR spectra proved the presence of hydroxyl groups on the catalyst's surface responsible for the photocatalytic activity and proved the absence of any chemical bonding between $\mathrm{Ag}$ nanoparticles and $\mathrm{SnO}_{2}-\mathrm{g}-\mathrm{C}_{3} \mathrm{~N}_{4}$. Increased absorbance of the photocatalyst in the visible light region was proved by UV analysis, and PL analysis indicated that loading more $\mathrm{Ag}$ on the nanoparticle could lead to better performance. TEM analysis indicated the presence of small, spherical $\mathrm{SnO}_{2}$ nanoparticles $(\sim 3 \mathrm{~nm})$ uniformly distributed over g- $\mathrm{C}_{3} \mathrm{~N}_{4}$. HRTEM confirmed the crystalline nature of $\mathrm{SnO}_{2}-\mathrm{g}-\mathrm{C}_{3} \mathrm{~N}_{4}$ nanosheets. Photoelectrochemical studies of FTO-modified $\mathrm{Ag} @ \mathrm{SnO}_{2}-\mathrm{g}-\mathrm{C}_{3} \mathrm{~N}_{4}$ nanostructures showed that combining $\mathrm{SnO}_{2}$ onto g- $\mathrm{C}_{3} \mathrm{~N}_{4}$ improved recombination lifetime by forming a heterojunction that effectively separates electron-hole pair. Moreover, EIS analysis proves lower charge transfer resistance of the FTOmodified $\mathrm{Ag} @ \mathrm{SnO}_{2}-\mathrm{g}-\mathrm{C}_{3} \mathrm{~N}_{4}$ nanostructures. The rate constants for the degradation of $\mathrm{MB}, \mathrm{CR}$,

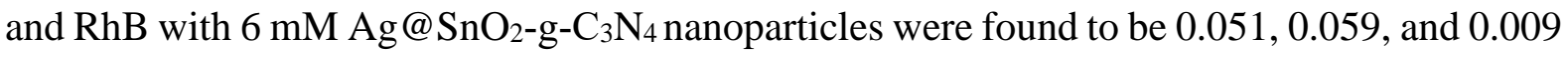
$\mathrm{min}^{-1}$, respectively, and the reactive oxygen species responsible for the photocatalytic degradation are ${ }^{\circ} \mathrm{OH}$ and ${ }^{\circ} \mathrm{O}^{2-}[25]$.

Degradation studies of $\mathrm{RhB}$ were carried out using heterostructures of $\mathrm{CdS} / \mathrm{NaTaO}_{3}$ in the presence of visible light. The photocatalyst was prepared initially by surface functionalizing bare $\mathrm{NaTaO}_{3}$ using 3-mercaptopropionic acid, followed by fabrication of various concentrations of $\mathrm{CdS}$. The average particle size of $\mathrm{NaTaO}_{3}$ is $100 \mathrm{~nm}$ with a cube shape and synthesized by hydrothermal method. The heterojunction is responsible for decreased electronhole pair recombination and hence enhanced photocatalytic activity. Raman spectroscopy and PXRD analysis indicated the existence of $\mathrm{NaTaO}_{3}$ in both monoclinic and orthorhombic phases. FESEM, TEM and HRTEM analysis of $\mathrm{NaTaO}_{3}$ nanocubes with uniform spherical 10 nm-sized CdS nanoparticles on its surface retained the shape of $\mathrm{NaTaO}_{3}$ but making the surface rough. BET analysis indicated that incorporation of CdS nanoparticles resulted in increased surface area and pore size making the material mesoporous. The optimum concentration is $\mathrm{CdS}$ molar ratio of 8 in $\mathrm{Cd} / \mathrm{Ta}$ heterostructures. The degradation efficiency of the photocatalyst for $\mathrm{RhB}$ is $97.2 \%$ and the degradation time is 110 minutes, and the rate constant of the reaction is $0.327 \mathrm{~min}^{-1}$. After recycling for 3 times, the degradation efficiency was found to be $93.2 \%$. High crystallinity, expanded visible-light absorption, high surface area, and efficient photogenerated charge carrier separation are few factors that result in a potential photocatalyst for efficient dye degradation [26]. 
Four different orthorhombic nanomaterials of iron-(oxalate) capped $\mathrm{Fe}, \mathrm{Cu}, \mathrm{Co}$, and $\mathrm{Mn}$ doped heterobimetallic oxide were synthesized by a redox reaction between $[\mathrm{Fe}(\mathrm{ox})-\mathrm{Fe}(0)]$ and $\mathrm{CuSO}_{4}, \mathrm{CoNO}_{3}$, and $\mathrm{KMnO}_{4}$ in water for dye degradation of $\mathrm{MB}$ and other dyes into $\mathrm{CO}_{2}$, $\mathrm{NO}_{3}{ }^{-}$, and $\mathrm{SO}_{4}{ }^{2-}$. Holes and hydroxyl radicals are majorly responsible for the photocatalytic activity of the nanomaterial. It was observed that protonated MB undergoes faster degradation than neutral MB in acidic $\mathrm{pH}$ due to its increased adsorption to the negatively charged catalyst's surface. The nanomaterials also showed degradation of phenol and the rate of degradation decreases in the order: UV > yellow LED > visible light and $\mathrm{Fe}(\mathrm{ox}) \mathrm{Fe}-\mathrm{MnO}_{\mathrm{x}}>\mathrm{Fe}(\mathrm{ox})-\mathrm{Fe}_{3} \mathrm{O}_{4}$ $>\mathrm{Fe}(\mathrm{ox}) \mathrm{FeCoO}_{\mathrm{x}}>\mathrm{Fe}(\mathrm{ox}) \mathrm{Fe}-\mathrm{CuO}_{\mathrm{x}}$ with photocatalysts for both phenol and dyes. XRD analysis confirmed amorphous nature of $\mathrm{Fe}(\mathrm{ox}) \mathrm{Fe}-\mathrm{MnO}_{\mathrm{x}}$ and orthorhombic form of $\mathrm{Fe}(\mathrm{ox})-\mathrm{Fe}_{3} \mathrm{O}_{4}$, $\mathrm{Fe}(\mathrm{ox}) \mathrm{Fe}-\mathrm{CuO}_{\mathrm{x}}$ and $\mathrm{Fe}(\mathrm{ox}) \mathrm{Fe}-\mathrm{CoO}_{\mathrm{x}}$, whereas HR-SEM images confirmed nanoribbon-like structures for $\mathrm{Fe}(\mathrm{ox})-\mathrm{Fe}_{3} \mathrm{O}_{4}$, particle-like nature for $\mathrm{Fe}(\mathrm{ox}) \mathrm{Fe}-\mathrm{MnO}_{\mathrm{x}}$ and flower-like morphology for $\mathrm{Fe}(\mathrm{ox}) \mathrm{Fe}-\mathrm{CuO}_{\mathrm{x}}$ and $\mathrm{Fe}(\mathrm{ox}) \mathrm{Fe}-\mathrm{CoO}_{\mathrm{x}}$. HRTEM analysis indicated porous morphology for $\mathrm{Fe}(\mathrm{ox}) \mathrm{Fe}-\mathrm{CoO}_{\mathrm{x}}$ and $\mathrm{Fe}(\mathrm{ox}) \mathrm{Fe}-\mathrm{MnO}_{\mathrm{x}}$. The rate constant for $\mathrm{Fe}(\mathrm{ox}) \mathrm{Fe}-\mathrm{MnO}_{\mathrm{x}}$ in the presence of visible light is $17 \times 10^{-3}$ for $\mathrm{MB}$ and $12.1 \times 10^{-4} \mathrm{~min}^{-1}$ for phenol. The nanomaterial can be used to degrade dyes like methylene blue (MB), malachite green (MG), crystal violet (CV), and methyl violet (MV). However, they show no photocatalytic activity towards dyes like rose Bengal, methyl orange, methyl red, and congo red due to the lack of binding of neutral and anionic dyes to the negatively charged photocatalyst. It is also observed that $\mathrm{Fe}(\mathrm{ox}) \mathrm{Fe}-\mathrm{CoO}_{\mathrm{x}}$ exhibited the most efficient degradation even after 10 cycles, whereas the other nanomaterials exhibited significant efficiency loss and leaching of metals. For large-scale photocatalytic degradation, although the best efficiency was exhibited by $\mathrm{Fe}(\mathrm{ox}) \mathrm{Fe}-\mathrm{MnO}_{\mathrm{x}}$ $\mathrm{Fe}(\mathrm{ox}) \mathrm{Fe}-\mathrm{CoO}_{\mathrm{x}}$ proved to be the most stable nanomaterial [27].

Degradation of $\mathrm{RhB}$ using Keplerate $\left\{\mathrm{Mo}_{72} \mathrm{Fe}_{30}\right\}$ nanoclusters was studied. Due to greater surface area, higher pore volume, and negative surface charges amorphous form of Keplerate is considered superior to its rhombohedral crystalline form. Electron transfer from excited polyoxometalates (POM), which produced $\mathrm{RhB}^{+}$and reduced $\mathrm{POM}\left(\mathrm{POM}^{-}\right)$is predicted as a probable mechanism for photocatalytic degradation. The photocatalyst exhibits $100 \%$ degradation efficiency in 1 hour. However, in large-scale degradation, efficiency slightly reduces to $87 \%$ in 4 hours. The optimum $\mathrm{pH}$ to be maintained is 2.5 , and the optimum dosage of catalyst is $3 \mathrm{mg}$ in $50 \mathrm{~mL} \mathrm{RhB}$ solution. Although both anionic and cationic dyes undergo degradation, efficiency is lower for anionic dyes like MO. The catalyst was stable for 5 cycles [28].

Titanium dioxide $\left(\mathrm{TiO}_{2}\right)$ decorated elongated rhombic shape silver chromate $\left(\mathrm{Ag}_{2} \mathrm{CrO}_{4}\right)$ was coupled with gold $(\mathrm{Au})$ and reduced graphene oxide by impregnation and in situ reduction with acacia gum, a reducing and stabilizing agent, to prepare a biogenic photocatalyst and study the degradation of MB dye. The photocatalyst exhibited a degradation efficiency of $97 \%$ in 52 minutes with a rate constant of $0.0566 \mathrm{~min}^{-1}$ and a high electron movement capacity. Incorporation of $\mathrm{Au}$ and $\mathrm{r}-\mathrm{GO}$ reduced band vitality increased light ingestion of quaternary $\mathrm{Ag}_{2} \mathrm{CrO}_{4} / \mathrm{TiO}_{2} / \mathrm{Au} / \mathrm{r}-\mathrm{GO}$ composite biofilm photocatalyst and decreased the rate of electronhole pair recombination. Decoration of $\mathrm{TiO}_{2}$, an electron sink, on $\mathrm{Ag}_{2} \mathrm{CrO}_{4}$ also plays a major role in delaying the recombination process. The degradation rate of the newly synthesized film was 10.8, 6.5, and 3.1 times faster than $\mathrm{Ag}_{2} \mathrm{CrO}_{4}, \mathrm{Ag}_{2} \mathrm{CrO}_{4} / \mathrm{TiO}_{2}$, and $\mathrm{Ag}_{2} \mathrm{CrO}_{4} / \mathrm{TiO}_{2} / \mathrm{Au}$ biofilms, each. FESEM analysis confirms 30-40 nm particle size of $\mathrm{TiO}_{2}$ nanoparticles, and XRD confirms orthorhombic $\mathrm{Ag}_{2} \mathrm{CrO}_{4}$, anatase $\mathrm{TiO}_{2}$, and fcc structure of Au. Degradation activity was mainly carried out due to the formation of active hydroxyl radicals and minorly 
due to the valence bond holes. The photocatalyst showed excellent stability with a degradation efficiency of $91 \%$ after 5 cycles [29].

A magnetically recoverable $\mathrm{NiFe}_{2} \mathrm{O}_{4} / 2 \mathrm{D}$ MoS2-Pd nanocomposite was synthesized to degrade $\mathrm{RhB}$ dye using the hydrothermal method. $\mathrm{NiFe}_{2} \mathrm{O}_{4} / 2 \mathrm{D} \mathrm{MoS}_{2} \mathrm{p}$-n heterojunction was formed by the interfacial contact between $\mathrm{NiFe}_{2} \mathrm{O}_{4}$ nanocubes and corrugated $\mathrm{MoS}_{2}$ nanosheets with Pd nanoparticles distributed uniformly on the surface, and it has improved light absorption efficiency. Here, Pd nanoparticles act as an electron reservoir and lead to localized surface plasmon resonance (LSPR), $\mathrm{MoS}_{2}$ has a large surface area, high thermal stability with greater adsorption ability towards $\mathrm{RhB}$ dye, and $\mathrm{NiFe}_{2} \mathrm{O}_{4}$ gives good magnetic separability and catalytic recyclability and thereby together enhance the photocatalytic dye degradation process. SEM and TEM images indicated curled paper-like morphology for $\mathrm{MoS}_{2}$ nanosheets without any stacking. In situ formation of $\mathrm{Pd}$ nanoparticles and $\mathrm{NiFe} 2 \mathrm{O} 4$ nanocubes that homogeneously intercalate into $\mathrm{MoS}_{2}$ layers prevent restacking of $\mathrm{MoS}_{2}$ nanosheets. They also indicate the uniform distribution of Pd nanoparticles over the surface. Pd nanoparticles have an average diameter of $4 \mathrm{~nm}$. The hybrid photocatalyst showed a degradation efficiency of 95.3 $\%$ for $\mathrm{RhB}$ in 30 minutes compared to $59.2 \%$ for a physical mixture of $\mathrm{NiFe}_{2} \mathrm{O}_{4}+2 \mathrm{D} \mathrm{MoS}_{2}-$ Pd. Superoxide and hydroxyl radicals play a major role in photocatalytic degradation. The photocatalyst exhibited stability up to 3 cycles with no significant loss of activity [30].

Reduced graphene oxide ( $\mathrm{rGO}$ ) decorated with neodymium, nitrogen, and sulfur tridoped titania $\left(\mathrm{Nd}, \mathrm{N}, \mathrm{S}-\mathrm{TiO}_{2}\right)$ was used to check photocatalytic degradation of erichrome black $\mathrm{T}$ (EBT) and eosin blue shade (EBS) in sunlight and was compared with the degradation activity of corresponding MWCNTs. The degradation was carried out in both single and mixed dye solutions, and degradation of $99.3 \%$ was observed in the case of EBS and $94.6 \%$ in the case of EBT in single dye solution and $65.7 \%$ and $58.9 \%$, respectively, a mixed dye solution. The degradation values are higher than that of commercial and tridoped titania. The rate constant for EBS degradation was found to be $1.4 \times 10^{-2}$ and $1.9 \times 10^{-2} \mathrm{~min}^{-1}$ for MWCNT/Nd,N,S-TiO and $\mathrm{rGO} / \mathrm{Nd}, \mathrm{N}, \mathrm{S}-\mathrm{TiO}_{2}$, respectively. On the other hand, for EBT the values were $8.0 \times 10^{-3}$ and $1.1 \times 10^{-2} \mathrm{~min}^{-1}$ for MWCNT/Nd,N,S-TiO 2 , and $\mathrm{rGO} / \mathrm{Nd}, \mathrm{N}, \mathrm{S}-\mathrm{TiO}_{2}$, respectively. Superoxide and hydroxyl radicals are the active species responsible for photocatalytic degradation. Carbon nanomaterials like CNTs and rGOs help improve optical and photocatalytic properties compared to pure titania by increasing the surface area of the catalyst, adsorption capacity for pollutants, and decreasing titania nanoparticles' aggregation. TEM and FE-SEM analyses suggest full coverage of reduced graphene sheets by titania nanoparticles. Unlike MWCNTs, there is more interaction between graphene sheets and tridoped titania, leading to better light absorption of the formation of sub-bandgap states in the titania bandgap. XRD patterns suggest the crystalline nature of photocatalyst with the anatase phase of titania. Peaks due to $\mathrm{Nd}_{2} \mathrm{O}_{3}$ are absent, which indicates its small amount compared to titania and that it has been well dispersed within the titania matrix. The surface areas of $\mathrm{rGO} / \mathrm{Nd}, \mathrm{N}, \mathrm{S}-\mathrm{TiO}_{2}$ and $\mathrm{MWCNT} / \mathrm{Nd}, \mathrm{N}, \mathrm{S}-\mathrm{TiO}_{2}$ are 144.87 and $128.21 \mathrm{~m}^{2} / \mathrm{g}$, respectively, which is higher compared to tridoped titania with a surface area of $78.21 \mathrm{~m}^{2} / \mathrm{g}$. TOC values of $82.0 \%$ and $75.6 \%$ were obtained for EBS and EBT, indicating fairly high degradation of both the dyes. $\mathrm{Nd}^{3+}$ helps increase charge separation and rGOs and MWCNTs in increasing surface area and preventing aggregation of titania nanoparticles. As a result, they contribute towards enhancing the photocatalytic activity of the catalyst [18].

Gold nanoparticle-mixed metal oxide nanocomposites were synthesized by selfassembly, dihydrolipoic acid (DHLA)-capped gold nanoparticle solution, and mixed metal 
oxide (MMO) nanoplates were prepared. The synthesized photocatalyst was then tested for degradation activity against Orange II azo dye under visible light. The DHLA-capped gold nanoparticle had an average diameter of $3.6 \mathrm{~nm}$, a hydrodynamic diameter of $4.7 \mathrm{~nm}$, and was pseudospherical in shape. The MMO nanoplates had hexagonal shapes and a lateral dimension of 100-250 nm. The mechanism followed in this process is as follows: under visible light irradiation, the dye molecule gets excited and transfers the electrons to the semiconductor photocatalyst's conduction band, which is trapped by the oxygen molecules adsorbed on its surface. As a result, reactive oxidation species are generated that eventually results in either self-degradation of the dye or degradation due to the reactive oxidation species. $99.9999 \%$ of the dye degraded in 2 hours' time, and the photocatalyst could be efficiently reused up to 5 cycles. Au NPs acting as electron sink is the major highlight of this method, which helps efficient visible-light photocatalysis [31].

$\mathrm{Ag}$ nanotubes were synthesized from copper nanowires, and by reaction with $\mathrm{FeCl}_{3}$ hollow plasmonic Ag@AgCl nanotubes were obtained. The degradation of MO was studied, and it was observed that the photocatalyst showed a degradation efficiency of $92.58 \%$, and the dye degraded in just 10 minutes. The tubulate structure of the photocatalyst provides a larger surface, including the inner and outer surface areas, and acts as a trap-well for photons, which increases light absorption and improves photocatalytic activity. SEM and TEM images indicate the diameter of the photocatalyst to be $0.5-1.5 \mu \mathrm{m}$. The rough and porous surface of the catalyst also helps in enhancing the absorption of the dye. Although Ag nanotube is silk-grey in color, $\mathrm{Ag} @ \mathrm{AgCl}$ nanotube is purple. The absorption range increases from 350-800 nm in the case of $\mathrm{Ag} @ \mathrm{AgCl}$ nanotube compared to 200-350 nm in the case of $\mathrm{Ag}$ nanotubes. It was observed that the highest photocatalytic activity was obtained when Fe and $\mathrm{Ag}$ were mixed in 1:1 ratio. $\mathrm{Cl}^{\mathrm{O}}$ and superoxide radicals are responsible for degradation, and the recyclability of the catalyst is 4 . The catalyst showed similar results for degradation of $\mathrm{RhB}$ as well, and degradation efficiency of $88 \%$ was observed for phenol [32].

$\mathrm{AgBr} / \mathrm{Ag}_{3} \mathrm{PO}_{4}$ decorated ceria nanoflake composites were used for photocatalytic degradation of methylene blue and Methyl orange (anionic and cationic dyes) under visible light. It also showed antimicrobial activity, which was demonstrated with the help of E.coli bacteria. Silver semiconductors help in reducing the rate of electron-hole pair recombination, which enhances photocatalytic activity. Silver ions are also well known for their antibacterial activity. XRD analysis indicates fcc structure for $\mathrm{AgBr}$ and $\mathrm{Ag}_{3} \mathrm{PO}_{4}$. Ceria usually absorbs in the UV region. However, coupling it with $\mathrm{AgBr}$ and $\mathrm{Ag}_{3} \mathrm{PO}_{4}$ shifts the absorbance visible light region due to the presence of $\mathrm{Ce}^{3+}$. SEM analysis proves the flake structure of ceria in the synthesized photocatalyst. When combined with $\mathrm{AgBr}$ and $\mathrm{Ag}_{3} \mathrm{PO}_{4}$, the surface areas of the photocatalyst are 92 and $76 \mathrm{~m}^{2} / \mathrm{g}$, which are lower than pristine and PEG-assisted ceria. TEM analysis indicated that the size of ceria nanoflakes was between 100 and $200 \mathrm{~nm}$. XPS analysis shows the presence of both $\mathrm{Ce}^{3+}$ and $\mathrm{Ce}^{4+}$ and $\mathrm{Ag}$ in the ground state. $\mathrm{AgBr} / \mathrm{Ag}_{3} \mathrm{PO}_{4} /$ ceria composite exhibited maximum degradation, whereas the least activity was exhibited by $\mathrm{AgBr} /$ ceria composite. The rate constant of $\mathrm{AgBr} / \mathrm{Ag}_{3} \mathrm{PO}_{4} /$ ceria composite for degradation of Methylene blue is $577 \pm 4.3 \times 10^{-4} \mathrm{~min}^{-1}$ and for Methyl orange is $339 \pm 3.3 \times 10^{-4} \mathrm{~min}^{-1}$. It also shows antimicrobial activity against E.coli with a rate constant of $206.8 \pm 2.9 \times 10^{-4} \mathrm{~min}^{-1}$. Bacterial activity is caused due to the formation of hydroxyl and superoxide radicals and hydrogen peroxide. On the other hand, dye degradation was mainly caused due to holes followed by hydroxyl and superoxide radicals. The catalyst could be reused 7 times [33]. 
Electrochemically active biofilms supported on carbon paper were used to synthesize $\mathrm{Au} @ \mathrm{CeO}_{2}$ nanocomposites in water at 30 degrees Celsius and normal pressure. Hence, fossil fuel needs to maintain reaction conditions, use of harmful chemicals, capping, and reducing agents could be eliminated. The optical and visible light photocatalytic activity was mainly enhanced due to the interfaces present between $\mathrm{Au} N \mathrm{NPs}$ and $\mathrm{CeO}_{2} . \mathrm{MO}$ and $\mathrm{MB}$ were used to analyze the degradation activity. Au NPs help $\mathrm{CeO}_{2}$ absorb light in the visible region. PL spectrum revealed fluorescence quenching from $\mathrm{CeO}_{2}$ by $\mathrm{Au}$ NPs due to strong anchoring of Au nanoparticles and, as a result, reduces electron-hole recombination rate. SEM and TEM analysis revealed mostly cube-shaped $\mathrm{CeO}_{2}$, although some were diamond and triangular in shape and their sizes ranged from 20 to $30 \mathrm{~nm}$. HAADF-STEM image suggests a polycrystalline structure for $\mathrm{Au} @ \mathrm{CeO}_{2}$ nanocomposites where 2 phases had fcc lattices. $\mathrm{Au}$ NPs had a size ranging from 6-10 nm, were evenly distributed over $\mathrm{CeO}_{2}$ surface, and did not undergo self-aggregation. XPS analysis proved $\mathrm{Ce}^{4+}$ state of $\mathrm{CeO}_{2}$ and the ground state of gold NPs. The degradation efficiency for MO is $80 \%$ in 6 hours, and MB is $95 \%$ in 5 hours. Superoxide and hydroxyl radicals are responsible for the degradation process. The catalyst could be reused 3 times which reduces degradation efficiency only to $90 \%$ [34].

$\mathrm{Ag}_{2} \mathrm{~S}$-grafted $\mathrm{NiO}-\mathrm{ZnO}$ ternary nanocomposites were synthesized by precipitation method and used for visible-light photocatalytic degradation against $\mathrm{RhB}$ with a degradation efficiency equal to $95 \%$ in 120 minutes. The best activity was exhibited by $8 \%$ $\mathrm{Ag}_{2} \mathrm{~S} / \mathrm{NiO}-\mathrm{ZnO}(\mathrm{AZN}-8)$, and the species responsible for degradation activity are superoxide and hydroxyl radicals. A rate constant of $0.0302 \mathrm{~min}^{-1}$ was observed for the degradation of the dye molecule. Surface plasmon resonance of silver plays a major role in enhancing the photocatalytic activity of the nanomaterial. XRD analysis proved the hexagonal shape of $\mathrm{ZnO}$ and fcc structure of NiO. TEM analysis predicted the spherical shape of $\mathrm{NiO}$ particles. The randomly scattered $\mathrm{Ag}_{2} \mathrm{~S}$ NPs on $\mathrm{NiO}-\mathrm{ZnO}$ surface create irregularities and contribute to better photocatalytic activity. The photocatalyst retained a degradation efficiency of $85 \%$ after 6 recycles. The photocatalyst also has the ability to detect acetone with a sensitivity of 4.0764

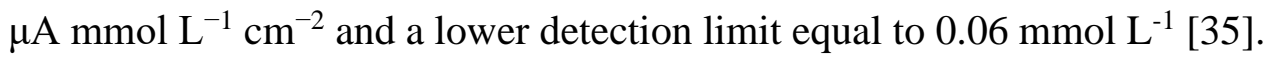

\section{Discussion}

Various research articles based on visible-light active nanomaterials for dye degradation were reviewed. Nanomaterials such as wsGNS, PANI/RGO, Cu1.94S-rGO, Ag@ $\mathrm{SnO}_{2}-\mathrm{g}-\mathrm{C}_{3} \mathrm{~N}_{4}$, $\mathrm{CdS} / \mathrm{NaTaO}_{3}, \quad \mathrm{Fe}\left(\right.$ ox)Fe-MnO,$\quad \mathrm{Fe}\left(\right.$ ox)Fe-CoO $, \quad \mathrm{Mo}_{2} \mathrm{Fe}_{30}, \quad \mathrm{Ag}_{2} \mathrm{CrO}_{4} / \mathrm{TiO}_{2} / \mathrm{Au} / \mathrm{r}-\mathrm{GO}$, $\mathrm{NiFe}_{2} \mathrm{O}_{4} / 2 \mathrm{D} \mathrm{MoS}_{2}-\mathrm{Pd}, \mathrm{rGO} / \mathrm{Nd}, \mathrm{N}, \mathrm{S}-\mathrm{TiO}_{2}, \mathrm{Au} \mathrm{NP}-\mathrm{MMO}, \mathrm{Ag} @ \mathrm{AgCl}, \mathrm{AgBr} / \mathrm{Ag}_{3} \mathrm{PO}_{4} /$ ceria, $\mathrm{Au} @ \mathrm{CeO}_{2}$, and $\mathrm{Ag}_{2} \mathrm{~S} / \mathrm{NiO}-\mathrm{ZnO}$ were used to study the degradation of dyes such as $\mathrm{MB}, \mathrm{MG}$, $\mathrm{RhB}, \mathrm{CR}, \mathrm{MO}$, Crystal violet, EBS, EBT, and Orange II. Among the research articles reviewed, 6 catalysts were used for degradation of $\mathrm{RhB}$ dye, 6 for $\mathrm{MB}, 4$ for $\mathrm{MO}, 2$ for $\mathrm{CR}$, and 1 each for other dyes. PANI/RGO could degrade $\mathrm{MG}, \mathrm{RhB}$, and $\mathrm{CR}, \mathrm{Ag} @ \mathrm{SnO}_{2}-\mathrm{g}-\mathrm{C}_{3} \mathrm{~N}_{4}$ could degrade $\mathrm{MB}, \mathrm{CR}$, and $\mathrm{RhB}, \mathrm{Cu}_{1.94} \mathrm{~S}-\mathrm{rGO}$ could degrade $\mathrm{MO}$ and Crystal violet, $\mathrm{Au} @ \mathrm{CeO}_{2}$, and $\mathrm{AgBr} / \mathrm{Ag}_{3} \mathrm{PO}_{4} /$ ceria could degrade both $\mathrm{MO}$ and $\mathrm{MB}$ and $\mathrm{rGO} / \mathrm{Nd}, \mathrm{N}, \mathrm{S}-\mathrm{TiO}_{2}$ could degrade EBS and EBT.

The catalysts used for the degradation of $\mathrm{RhB}$ are PANI/RGO, AZN-8, $\mathrm{Ag} @ \mathrm{SnO}_{2}-\mathrm{g}-\mathrm{C}_{3} \mathrm{~N}_{4}, \mathrm{CdS} / \mathrm{NaTaO}_{3}, \mathrm{Mo}_{2} \mathrm{Fe}_{30}$, and $\mathrm{NiFe}_{2} \mathrm{O}_{4} / 2 \mathrm{D} \quad \mathrm{MoS}_{2}-\mathrm{Pd}$. The highest degradation efficiency $(100 \%)$ is exhibited by $\mathrm{Mo}_{22} \mathrm{Fe}_{30}$, whereas the highest no of recycles ( $\mathrm{n}$ =6) was possible using PANI/RGO with a recycling efficiency of $87.12 \%$. For MB, the highest degradation efficiency of $99.4 \%$ was exhibited by $\mathrm{Ag} @ \mathrm{SnO}_{2}-\mathrm{g}-\mathrm{C}_{3} \mathrm{~N}_{4}$, whereas the highest 
number of recycles was possible using $\mathrm{AgBr} / \mathrm{Ag}_{3} \mathrm{PO}_{4} /$ ceria nanomaterial. In the case of $\mathrm{MO}$, maximum degradation efficiency $(92.58 \%)$ and the maximum number of recycles were obtained using $\mathrm{Ag} @ \mathrm{AgCl}$ nanotubes. Both photocatalysts PANI/RGO and $\mathrm{Ag} @ \mathrm{SnO}_{2}-\mathrm{g}-\mathrm{C}_{3} \mathrm{~N}_{4}$ used to degrade CR dye showed almost equal degradation efficiencies of 98.73 and $98.28 \%$. However, with PANI/RGO the time required to degrade was lesser (40 minutes) compared to that required by $\mathrm{Ag} @ \mathrm{SnO}_{2}-\mathrm{g}-\mathrm{C}_{3} \mathrm{~N}_{4}$ (60 minutes), and the rate constant is also higher for PANI/RGO $\left(0.109 \mathrm{~min}^{-1}\right)$ with not much loss in efficiency after 6 recycles. Hence PANI/RGO would be a better visible-light active photocatalyst for CR.

The advantage of using wsGNS photocatalyst to degrade MB dye is that it is a highly stable, recoverable, and reusable photocatalyst derived from pollutant soot using a low-cost, facile, metallic contamination-free method. PANI/RGO is a nanocomposite capable of absorbing the entire portion of the solar spectrum. It also efficiently removes $\mathrm{Cr}(\mathrm{VI})$ up to $94.7 \%$ at $\mathrm{pH} 2$ in only 15 minutes. $\mathrm{Cu}_{1.94} \mathrm{~S}$-rGO nanomaterial, along with degradation of $\mathrm{MO}$ dye and Crystal violet, also shows a good response toward phenol in $0.2 \mu \mathrm{M}$ to $1.4 \mu \mathrm{M}$ concentration range. But it was observed that the carbon framework disintegrates due to the removal of oxygen-containing groups when the temperature rises from $250-800^{\circ} \mathrm{C}$, and the wet hydrogen peroxide catalytic oxidation (WHPCO) method is required for enhanced photocatalytic degradation. More the concentration of hydrogen peroxide greater the number of hydroxyl radicals generated for photodegradation and reduces electron-hole pair recombination. The advantage of using $\mathrm{NiFe}_{2} \mathrm{O}_{4} / 2 \mathrm{D} \mathrm{MoS}_{2}-\mathrm{Pd}$ photocatalyst is that is a magnetically recoverable catalyst. And can be used as a catalyst for the Suzuki-Miyaura coupling reaction. On the other hand, $\mathrm{AgBr} / \mathrm{Ag}_{3} \mathrm{PO}_{4} /$ ceria nanomaterial showcases antimicrobial property along with dye degradation. $\mathrm{Ag} @ \mathrm{AgCl}$ nanomaterial exhibits similar degradation efficiency for $\mathrm{RhB}$ as $\mathrm{MO}$ and also degrades phenol by $88 \%$. A green method was adopted to synthesize $\mathrm{Au} @ \mathrm{CeO}_{2}$ to degrade $\mathrm{MO}$ and $\mathrm{MB}$, without burning fossil fuels and avoiding the use of toxic chemicals. AZN photocatalyst also has the ability to detect acetone with high sensitivity, and it degrades RhB by $95 \%$.

Meanwhile, orthorhombic iron-(oxalate) capped $\mathrm{Fe}, \mathrm{Cu}, \mathrm{Co}$, and $\mathrm{Mn}$-doped heterobimetallic oxide nanomaterials exhibit the highest photocatalytic activity in the presence of UV light and least in the presence of visible light. Moreover, they show no photocatalytic activity towards dyes like rose Bengal, methyl orange, methyl red, and congo red due to lack of binding of neutral and anionic dyes to the negatively charged photocatalyst. Similarly, Keplerate $\left\{\mathrm{Mo}_{2} \mathrm{Fe}_{30}\right\}$ does not degrade anionic dyes efficiently, and with an increase in $\mathrm{pH}$ of the medium above 5, photocatalytic efficiency decreases. But it shows $87 \%$ degradation efficiency towards $\mathrm{RhB}$ in large-scale degradation.

\section{Conclusions}

Although many toxic dyes are released into water bodies by various industries every year without proper treatment, various scientific methods have been identified to treat contaminated water. The use of visible-light active nanomaterials has been the recent advanced, costeffective technology preferred by many scientists to degrade such harmful dyes to simpler and less harmful compounds like $\mathrm{CO}_{2}$ and $\mathrm{H}_{2} \mathrm{O}$. Few relevant research articles published in ACS since 2012 were reviewed to study various visible-light active nanomaterials available for dye degradation. Among the photocatalysts used to degrade Rhodium B dye highest efficiency was exhibited by $\mathrm{Mo}_{2} \mathrm{Fe}_{30}$, whereas PANI/RGO along with degradation of RhB could degrade Malachite green, Congo red dyes as well as Cr (VI) and could be reused in 6 cycles. For 
methylene blue best efficiency was exhibited by Ag@ $\mathrm{SnO}_{2}-\mathrm{g}-\mathrm{C}_{3} \mathrm{~N}_{4}$, and in the case of methyl orange, it was $\mathrm{Ag} @ \mathrm{AgCl}$ nanotubes. However, for $\mathrm{CR}$ degradation PANI/RGO is a better photocatalyst than $\mathrm{Ag} @ \mathrm{SnO}_{2}-\mathrm{g}-\mathrm{C}_{3} \mathrm{~N}_{4}$.

Table 1. Performance summary of visible-light active nanomaterials for dye degradation.

\begin{tabular}{|c|c|c|c|c|c|c|c|}
\hline Photocatalyst & Dye & $\begin{array}{l}\text { Degradation } \\
\text { efficiency }(\%)\end{array}$ & $\begin{array}{l}\text { Time } \\
\text { (min) }\end{array}$ & $\begin{array}{l}\text { Rate } \\
\text { constant } \\
(\mathbf{k})\left(\mathrm{min}^{-1}\right)\end{array}$ & $\begin{array}{l}\text { No. of } \\
\text { recycles }\end{array}$ & $\begin{array}{l}\text { Recycling } \\
\text { efficiency } \\
(\%)\end{array}$ & ref \\
\hline wsGNS & $\mathrm{MB}$ & 96 & 90 & 0.0313 & $\begin{array}{l}3 \\
5\end{array}$ & $\begin{array}{l}90 \\
75\end{array}$ & 31 \\
\hline \multirow[t]{3}{*}{ PANI/RGO } & MG & 99.68 & 15 & 0.384 & 6 & 86.63 & 34 \\
\hline & RhB & 99.35 & 30 & 0.168 & & 87.12 & \\
\hline & $\mathrm{CR}$ & 98.73 & 40 & 0.109 & & 92.78 & \\
\hline \multirow[t]{2}{*}{$\mathrm{Cu}_{1.94 \mathrm{~S}-\mathrm{rGO}}$} & $\mathrm{MO}$ & 79.44 & & 0.0019 & 4 & 74.34 & 35 \\
\hline & $\begin{array}{l}\text { Crystal } \\
\text { violet }\end{array}$ & 90.76 & & 0.0022 & & 83.96 & \\
\hline \multirow[t]{3}{*}{$\mathrm{Ag} @ \mathrm{SnO}_{2}-\mathrm{g}-\mathrm{C}_{3} \mathrm{~N}_{4}$} & $\mathrm{MB}$ & 99.4 & 90 & 0.051 & - & - & 36 \\
\hline & $\mathrm{CR}$ & 98.28 & 60 & 0.059 & - & - & \\
\hline & RhB & 94.67 & 240 & 0.009 & - & - & \\
\hline $\mathrm{CdS} / \mathrm{NaTaO}_{3}$ & RhB & 97.2 & 110 & 0.327 & 3 & 93.2 & 37 \\
\hline $\mathrm{Fe}($ ox $) \mathrm{Fe}-\mathrm{MnO}_{\mathrm{x}}$ & $\mathrm{MB}$ & - & - & 0.017 & 4 & - & 38 \\
\hline $\mathrm{Fe}(\mathrm{ox}) \mathrm{Fe}-\mathrm{CoO}_{\mathrm{x}}$ & - & - & - & - & 10 & - & \\
\hline $\mathrm{Mo}_{72} \mathrm{Fe}_{30}$ & RhB & 100 & 60 & - & 5 & - & 39 \\
\hline $\begin{array}{l}\mathrm{Ag}_{2} \mathrm{CrO}_{4} / \mathrm{TiO}_{2} / \mathrm{Au} / \\
\text { r-GO }\end{array}$ & MB & 97 & 52 & 0.0566 & 5 & 91 & 40 \\
\hline $\mathrm{NiFe}_{2} \mathrm{O}_{4} / 2 \mathrm{D} \mathrm{MoS}-\mathrm{Pd}$ & RhB & 95.3 & 30 & - & 3 & - & 41 \\
\hline \multirow[t]{2}{*}{$\mathrm{rGO} / \mathrm{Nd}, \mathrm{N}, \mathrm{S}-\mathrm{TiO}_{2}$} & EBS & 99.3 & 240 & & - & - & 29 \\
\hline & EBT & 94.6 & 240 & & - & - & \\
\hline Au NP-MMO & $\begin{array}{l}\text { Orange } \\
\text { II }\end{array}$ & 99.9999 & 120 & - & 5 & - & 42 \\
\hline $\mathrm{Ag} @ \mathrm{AgCl}$ & $\mathrm{MO}$ & 92.58 & 10 & - & 4 & - & 43 \\
\hline \multirow[t]{2}{*}{$\mathrm{AgBr} / \mathrm{Ag}_{3} \mathrm{PO}_{4} /$ ceria } & $\mathrm{MB}$ & - & 60 & 0.0577 & 7 & - & 44 \\
\hline & MO & - & 60 & 0.0339 & 7 & - & \\
\hline \multirow[t]{2}{*}{$\mathrm{Au} @ \mathrm{CeO}_{2}$} & $\mathrm{MO}$ & 80 & 360 & - & 3 & 90 & 45 \\
\hline & $\mathrm{MB}$ & 95 & 300 & - & 3 & 90 & \\
\hline $\begin{array}{l}\mathrm{Ag}_{2} \mathrm{~S} / \mathrm{NiO}-\mathrm{ZnO}(8 \%) \\
(\mathrm{AZN}-8)\end{array}$ & RhB & 95 & 120 & 0.0302 & 6 & 85 & 46 \\
\hline
\end{tabular}

\section{Funding}

This research received no external funding.

\section{Acknowledgments}

The authors thank Vellore Institute of Technology (VIT), Vellore - 632014, for the financial support, working platform, and instrument facilities are given to complete the study. Especially, the authors thank VIT, Vellore, for providing "VIT SEED GRANT" for carrying out this research work. 


\section{Conflicts of Interest}

The authors declare no conflict of interest.

\section{References}

1. Chen, D., Sivakumar, M., Ray, A.K. Heterogeneous photocatalysis in environmental remediation. Developments in Chemical Engineering and Mineral Processing 2000, 8, 505-550. https://doi.org/10.1002/apj.5500080507.

2. Palle, S.R., Penchalaneni, J., Lavudi, K., Gaddam, S.A., Kotakadi, V.S., Challagundala, V.N. Green Synthesis of Silver Nanoparticles by Leaf Extracts of Boerhavia erecta and Spectral Characterization and Their Antimicrobial, Antioxidant ad Cytotoxic Studies on Ovarian Cancer Cell Lines. Letters in Applied NanoBioScience 2020, 9, 1165-1176. https://doi.org/10.33263/LIANBS93.11651176.

3. Divya Kumar, M., Raji, P., Bennet Rohan, D., Gandham, R.G., Kripu Sharma, V., Keerthana, D., Karishma, S., Samrot, A.V., Ponnaiah, P., Thirumurugan, R., Pattammadath, S., Jenifer Selvarani, A., Prakash, P. Green Synthesis and antibacterial activity studies of silver nanoparticles from the aqueous extracts of Thespesia populnea. Letters in Applied NanoBioScience 2020, 9, 931-834. https://doi.org/10.33263/LIANBS91.931934.

4. Kumari, R., Mishra, R.C., Yadav, J.P. Antioxidant and cytotoxic studies of Acacia nilotica twig extract and their green synthesized silver nanoparticles. Letters in Applied NanoBioScience 2020, 9, 975-880. https://doi.org/10.33263/LIANBS92.975980.

5. Subhanandaraj, T.T., Raghavan, K.T., Narayanan, R. Antibacterial and antibiofilm activity of probiotic based silver nanoparticles is a green approach in biomedical applications. Letters in Applied NanoBioScience 2020, 9, 988-994. https://doi.org/10.33263/LIANBS92.988994.

6. Manikandan, S., Sankarlal, S., Singh, M., Sharma, A.K., Ganesapandian, S., Kumaraguru, A.K. Padina gymnospora derived a linear polysaccharide "alginate" mediated synthesis of silver nanocomposite and its antibacterial activity. Letters in Applied NanoBioScience 2020, 9, 1136-1140, https://doi.org/10.33263/LIANBS92.11361140.

7. Avinash Chunduri, L.A., Madhusudhana Rao, K., Vijaya Sai, K., Kurdekar, A.D., Prathibha, C., Kamisetti, V. Influence of Surface Charge on the Functional Properties of Silica Nanoparticles and Cellular Toxicity. Letters in Applied NanoBioScience 2020, 9, 1225-1238. https://doi.org/10.33263/LIANBS93.12251238.

8. El-Shanshoury, A.E.R.R., Ebeid, E.Z.E., Elsilk, S.E., Mohamed, S.F., Ebeid, M.E. Biogenic Synthesis of Gold Nanoparticles by Bacteria and Utilization of the Chemical Fabricated for Diagnostic Performance of Viral Hepatitis C Virus-NS4. Letters in Applied NanoBioScience 2020, 9, 1395-1408. https://doi.org/10.33263/LIANBS93.13951408.

9. Lagashetty, A.K., Ganiger, S.K., Reddy, S. Microwave Derived Nano Sized Zirconium Vanadate as an Adsorbent for Heavy Metal Ions. Letters in Applied NanoBioScience 2020, 9, 1420-1426. https://doi.org/10.33263/LIANBS93.14201426.

10. Krishnan, T., Mansor, W.S.W. Photocatalytic Degradation of Dyes by $\mathrm{TiO}_{2}$ Process in Batch Photoreactor. Letters in Applied NanoBioScience 2020, 9, 1502-1512. https://doi.org/10.33263/LIANBS94.15021512.

11. Gabal, R.A., Shalaby, R.M., Kamal, M., Abdelghany, A. Optimized Tin Bismuth Alloy Modified with Silver Vanadate Nanorods Prepared via Powder Metallurgy: Search for Biomedical Application. Letters in Applied NanoBioScience 2020, 9, 1615-1626. https://doi.org/10.33263/LIANBS94.16151626.

12. Narasaiah, B.P., Mandal, B.K. Bio-fabricated $\mathrm{CuO}$ NPs as green catalyst towards remediation of environmental pollutants. Letters in Applied NanoBioScience 2019, 8, 597-603. https://doi.org/10.33263/LIANBS83.597603.

13. Mathiyalagan, S., Mandal, B.K. Preparation of metal doped quercetin nanoparticles, characterization and their stability. Letters in Applied NanoBioScience 2019, 8, 704-710. https://doi.org/10.33263/LIANBS84.704710.

14. Ullah, N., Ullah, A., Rasheed, S. Green synthesis of copper nanoparticles using extract of Dicliptera Roxburghiana, their characterization and photocatalytic activity against methylene blue degradation. Letters in Applied NanoBioScience 2020, 9, 897-901. https://doi.org/10.33263/LIANBS91.897901.

15. Habtemariam, A.B., Assefu K. Sibhatu 1, Getu K. Weldegebrieal 1, Osman A. Zelekew 2, Belayhun T. Tekletsadik. Bio-mediated synthesis of $\mathrm{ZnO}$ nanostructures from Thymus Schimperi leaves extract and its antibacterial and photocatalytic activities. Letters in Applied NanoBioScience 2020, 8, 808-813. https://doi.org/10.33263/LIANBS91.808813. 
16. Priya, A., Saminathan, S., Balasundaram, J. Green synthesis of NiO nanoparticles using Leucas Aspera and its antibacterial activity. Letters in Applied NanoBioScience 2020, 9, 1033-1036. https://doi.org/10.33263/LIANBS92.10331036.

17. Gokduman, K. Comparison of the effect of magnetite $\left(\mathrm{Fe}_{3} \mathrm{O}_{4}\right)$ iron oxide nanoparticles on melanoma cells and healthy cells: an in vitro study. Letters in Applied NanoBioScience 2020, 9, 1049-1057. https://doi.org/10.33263/LIANBS92.10491057.

18. Mamba, G., Mamo, M.A., Mbianda, X.Y., Mishra, A.K. Nd, N, S-TiO 2 decorated on reduced graphene oxide for a visible light active photocatalyst for dye degradation: comparison to its MWCNT/Nd, N, S-TiO 2 analogue. Industrial \& Engineering Chemistry Research 2014, 53, 14329-14338. https://doi.org/10.1021/ie502610y.

19. Patra, A.S., Gogoi, G., Qureshi, M. Ordered-disordered $\mathrm{BaZrO}_{3}-\delta$ Hollow Nanosphere/Carbon Dot Hybrid Nanocomposite: A New Visible-Light-Driven Efficient Composite Photocatalyst for Hydrogen Production and Dye Degradation. ACS Omega 2018, 3, 10980-10991. https://doi.org/10.1021/acsomega.8b01577.

20. Singh, A., Khare, P., Verma, S., Bhati, A., Sonker, A.K., Tripathi, K.M., Sonkar, S.K. Pollutant Soot for Pollutant Dye Degradation: Soluble Graphene Nanosheets for Visible Light Induced Photodegradation of Methylene Blue, ACS Sustainable Chemistry and Engineering 2017, 5, 8860-8869. https://doi.org/10.1021/acssuschemeng.7b01645.

21. Qian, W., Zhao, K., Zhang, D., Bowen, C.R., Wang, Y., Yang, Y. Piezoelectric Material-Polymer Composite Porous Foam for Efficient Dye Degradation via the Piezo-Catalytic Effect. ACS Applied Materials \& Interfaces 2019, 11, 27862-27869. https://doi.org/10.1021/acsami.9b07857.

22. Williams, R.S., Alivisatos, P. Nanoscale Processes in the Environment," in Nanotechnology Research Directions: IWGN Workshop Report, Roco, M.C., Ed. Netherlands: Springer, 2000, 143-152. https://doi.org/10.1007/978-94-015-9576-6_10.

23. Mitra, M., Taheruddin Ahamed, S., Ghosh, A., Mondal, A., Kargupta, K., Ganguly, S., Banerjee, D. Polyaniline/Reduced Graphene Oxide Composite-Enhanced Visible-Light-Driven Photocatalytic Activity for the Degradation of Organic Dyes. ACS Omega 2019, 4, 1623-1635. https://doi.org/10.1021/acsomega.8b02941.

24. Dutta, S., Biswas, S., Maji, R.C., Saha, R. Environmentally Sustainable Fabrication of $\mathrm{Cu}_{1.94} \mathrm{~S}-\mathrm{rGO}$ Composite for Dual Environmental Application: Visible-Light-Active Photocatalyst and Room-Temperature Phenol Sensor. ACS Sustainable Chemistry and Engineering 2018, 6, 835-845. https://doi.org/10.1021/acssuschemeng.7b03186.

25. Mohammad, A., Rezaul Karim, M., Khan, M.E., Khan, M.M., Cho, M.H. Biofilm-Assisted Fabrication of $\mathrm{Ag} @ \mathrm{SnO}_{2}-\mathrm{g}-\mathrm{C}_{3} \mathrm{~N}_{4}$ Nanostructures for Visible Light-Induced Photocatalysis and Photoelectrochemical Performance. The Journal of Physical ChemistryC 2019, 123, 20936-20948. https://doi.org/10.1021/acs.jpcc.9b05105.

26. Singh, A.P., Kumar, S., Thirumal, M. Efficient Charge Transfer in Heterostructures of CdS/NaTaO3 with Improved Visible-Light-Driven Photocatalytic Activity. ACS Omega 2019, 4, 12175-12185. https://doi.org/10.1021/acsomega.9b01133.

27. Sarmah, K.; Pratihar, S. Synthesis, Characterization, and Photocatalytic Application of Iron Oxalate Capped $\mathrm{Fe}, \mathrm{Fe}-\mathrm{Cu}, \mathrm{Fe}-\mathrm{Co}$, and $\mathrm{Fe}-\mathrm{Mn}$ Oxide Nanomaterial. ACS Sustainable Chemistry and Engineering 2017, 5, 310-324. https://doi.org/10.1021/acssuschemeng.6b01673.

28. Garazhian, Z., Rezaeifard, A., Jafarpour, M., Farrokhi, A. \{Mo72Fe30\} Nanoclusters for the Visible-LightDriven Photocatalytic Degradation of Organic Dyes. ACS Applied Nano Materials 2020, 3, 648-657. https://doi.org/10.1021/acsanm.9b02174.

29. Biswas, R., Mete, S., Mandal, M., Banerjee, B., Singh, H., Ahmed, I., Haldar, K.K. Novel Green Approach for Fabrication of $\mathrm{Ag}_{2} \mathrm{CrO}_{4} / \mathrm{TiO}_{2} / \mathrm{Au} / \mathrm{r}-\mathrm{GO}$ Hybrid Biofilm for Visible Light-Driven Photocatalytic Performance. The Journal of Physical Chemistry C 2020, 124, 3373-3388. https://doi.org/10.1021/acs.jpcc.9b10866.

30. Fu, W., Xu, X., Wang, W., Shen, J., Ye, M. In-Situ Growth of $\mathrm{NiFe}_{2} \mathrm{O}_{4} / 2 \mathrm{D}$ MoS 2 p-n Heterojunction Immobilizing Palladium Nanoparticles for Enhanced Visible-Light Photocatalytic Activities," ACS Sustainable Chemistry and Engineering 2018, 6, 8935-8944. https://doi.org/10.1021/acssuschemeng.8b01299.

31. Cho, S.; Jang, J.-W.; Hwang, S.; Lee, J.F., Kim, S. Self-Assembled Gold Nanoparticle-Mixed Metal Oxide Nanocomposites for Self-Sensitized Dye Degradation under Visible Light Irradiation. Langmuir 2012, 28, 17530-17536. https://doi.org/10.1021/acssuschemeng.8b01299. 
32. Sun, L.; Zhang, R.; Wang, Y.; Chen, W. Plasmonic Ag@ AgCl Nanotubes Fabricated from Copper Nanowires as High-Performance Visible Light Photocatalyst. ACS Applied. Materials \& Interfaces 2014, 6, 1481914826. https://doi.org/10.1021/am503345p.

33. Eswar, N.K.R.; Katkard, V.V.; Ramamurthya, P.C.; and Madras, G. Novel AgBr/Ag $\mathrm{PO}_{4}$ Decorated Ceria Nanoflake Composites for Enhanced Photocatalytic Activity toward Dyes and Bacteria under Visible Light. Industrial \& Engineering Chemistry and Research 2015, 54, 8031-8042. https://doi.org/10.1021/acs.iecr.5b01993.

34. Khan, M.M.; Ansari, S.A.; Ansari, M.O; Min, B.K; Lee, J.; Cho, M.H. Biogenic Fabrication of $\mathrm{Au}_{0} \mathrm{CeO}_{2}$ Nanocomposite with Enhanced Visible Light Activity. Journal of Physical Chemistry C 2014, 118, 9477-9484. https://doi.org/10.1021/jp500933t.

35. Shafi, A.; Ahmad, N.; Sultana, S.; Sabir, S.; Khan, M.Z. Ag $_{2}$ S-Sensitized NiO-ZnO Heterostructures with Enhanced Visible Light Photocatalytic Activity and Acetone Sensing Property. ACS Omega 2019, 4, 1290512918. https://doi.org/10.1021/acsomega.9b01261. 